\title{
EVIDENCE OF NON-SYNAPTIC REGULATION OF POSTPARTUM UTERINE CONTRACTILITY IN THE RAT
}

\author{
R. Gáspár, A. Márki, I. Zupkó, G. Falkay \\ Department of Pharmacodynamics, Albert Szent-Györgyi Medical University, \\ H-6721 Szeged, P.O.Box 121, Hungary
}

(Received in final form January 7,1998 )

\begin{abstract}
Summary
Myometrial tissue rings from postpartum rats ( $24 \mathrm{~h}$ after delivery) were studied in vitro by electric field stimulation, and the $\alpha_{1} / \beta_{2}$-adrenoceptor ratio was determined by a radioligand binding technique. Pregnancy-denervated uterine rings were stimulated by long-duration pulses $(100 \mathrm{~ms})$. The contractions were inhibited by $\beta_{2}$-agonists (terbutaline and fenoterol) and $\alpha$-antagonists (phentolamine, urapidil and yohimbine) in a concentration-dependent manner. Their effects were not altered by the adrenergic neuron-blocking agent bretylium. The $\alpha$-antagonists (except phentolamine) elicited the same maximal inhibition as the $\beta_{2}$-agonists. Receptor assays revealed that the $\alpha_{1} / \beta_{2}$ ratio was about 2 in the measured uteri. It was concluded that the inhibitory effects of $\alpha$-antagonists and $\beta_{2}$-agonists are mediated via non-synaptic adrenoceptors of the denervated postpartum rat uterus. The same inhibitory activity could be explained by the greater amount of $\alpha$-receptors. It is belicved that this is the first functional proof of the existence of non-synaptic $\alpha_{1}$-adrenoceptors in smooth muscle.
\end{abstract}

Key Words: myometrium, electric field stimulation, receptor density, non-synaptic regulation

The adrenergic part of the autonomic nervous system plays an important role in the regulation of the motor activity of the uterus (1). This is reflected by clinical practice, $\beta_{2}$-agonists being among the most frequently used tocolytic drugs. It is well known that during pregnancy the adrenergic innervation of the uterus undergoes a significant change in many species, e.g. guinea pig, rabbit and human $(2,3,4)$. There is also a significant decrease in the number of adrenergic nerves in the final period of pregnancy of the rat, while the adrenergic

Corresponding author: George Falkay, Department of Pharmacodynamics, Albert Szent-Györgyi Medical University, H-6721 Szeged, P.O.Box 121, Tel/fax: (36)62-455-567, Hungary 
nerve ends and noradrenaline vesicles disappear during delivery (5). There is a similar phenomenon in humans (6). However, the sensitivity of the adrenoceptors of the surface of the smooth muscles remains or increases despite desympathization (2).

While the role of the $\beta$-receptors of the denervated myometrium during pregnancy has been demonstrated by clinical experience and results in several articles knowledge of the role of $\alpha$-receptors is limited. There is likewise very limited information as to whether adrenegic receptors in pregnancy, despite denervation, have connections with nerve ends or function independently from any synaptic junction. The latter is suggested by histological studies relating to $\beta$-receptors. One aim of our study was to clarify the role of $\alpha$-receptors in the regulation of the contractility of the pregnant uterus as compared to $\beta$-receptors. A further aim was to prove the synaptically independent function of adrenergic receptors in the pregnant myometrium. Our experiments were carried out on the isolated rat uterus by electric field stimulation (EFS) and on rat uterus membrane preparations by a radioreceptor binding assay.

\section{Methods}

\section{Uterus preparation and EFS}

Uteri were removed from Sprague-Dawley rats (200-250 g) $24 \mathrm{~h}$ after delivery. Muscle rings $0.5 \mathrm{~cm}$ long were sliced from the uterine horns and mounted vertically between two platinum electrodes in an organ bath containing $10 \mathrm{~mL}$ de Jongh solution (in mM: $137 \mathrm{NaCl}, 3$ $\mathrm{KCl}, 1 \mathrm{CaCl}_{2}, 1 \mathrm{MgCl}_{2}, 12 \mathrm{NaHCO}_{3}, 4 \mathrm{NaH}_{2} \mathrm{PO}_{4}, 6$ glucose; $\mathrm{pH}: 7.4$ ). The organ bath was maintained at $37{ }^{\circ} \mathrm{C}$ and carbogen $\left(95 \% \mathrm{O}_{2}+5 \% \mathrm{CO}_{2}\right)$ was bubbled through it. After mounting, the rings were equilibrated for about $1.5-2 \mathrm{~h}$ before experiments were undertaken. After the incubation period, rhythmic contractions were elicited by a digital, programmable stimulator (ST02, Experimetria Ltd. U.K.) using square pulses with a duration of $100 \mathrm{~ms}$ every $75 \mathrm{~s}$ at $40 \mathrm{~V}$. The tension of the myometrial rings was measured with a strain gauge transducer (SG-02, Experimetria Ltd. U.K.) and recorded by an ISOSYS Data Acquisition System (Experimetria Ltd. U.K.). Cumulative concentration-response curves to $\beta_{2}$-agonists and $\alpha$-antagonists have been constructed in each experiments. Areas under curves were evaluated and $\mathrm{EC}_{50}$ and maximal inhibition values were calculated with the Graphit 3.01 computer program. The maximal contractile response of each ring to electric field stimulation was used as reference and set at $100 \%$.

\section{Radioreceptor binding assays}

Radoligand binding experiments were carried out on the membrane preparation of a rat uterus postpartum ( $24 \mathrm{~h}$ after delivery) in Tris- $\mathrm{HCl}$ buffer (in $\mathrm{mM}: 50 \mathrm{Tris}-\mathrm{HCl}, 3 \mathrm{MgCl}_{2}, 1$ ascorbic acid; $\mathrm{pH}$ : 7.4). The uteri were removed and then were homogenized in twenty volumes (wt/vol) of ice-cold buffer (10 mM TRIS-HCl, $1 \mathrm{mM}$ EDTA, $0.6 \mathrm{mM} \mathrm{MgCl} 2,0.25 \mathrm{M}$ sucrose, $\mathrm{pH}$ 7.4) with Ultra Turrax T25 (Janke \& Kunkel) homogenizer, the suspension was filtered on four layers of gauze and centrifuged with Centrikon T-42K centrifuge $\left(40,000 \times \mathrm{g}, 4^{\circ} \mathrm{C}, 20 \mathrm{~min}\right)$. After the centrifugation the pellet was resuspended in $5 \mathrm{x}$ volumes of buffer. The membranes were stored in liquid nitrogen.

The reaction mixture contained $100 \mu 1$ tritiated ligand, $100 \mu l$ membrane preparation $(\sim 0.3$ $\mathrm{mg} / \mathrm{ml}$ protein) and $100 \mu \mathrm{l}$ unlabelled ligand $(10 \mu \mathrm{M})$ for non-specific binding or $100 \mu \mathrm{l}$ Tris- $\mathrm{HCl}$ 
buffer for total binding. Incubations were started by addition of the membrane suspension and continued in a shaking water bath until a steady-state was achieved $\left(30^{\circ} \mathrm{C}, 30 \mathrm{~min}\right)$. The reaction was terminated by rapid filtration on a Skatron 11019 cell harvester through Whatmann $\mathrm{GF} / \mathrm{C}$ filters and washed with $10 \mathrm{ml}$ of ice-cold TRIS-HCl ( $\mathrm{pH} \mathrm{7.4)} \mathrm{huffer.} \mathrm{The} \mathrm{bound} \mathrm{radioactivity} \mathrm{was}$ determined in a HighSafe ${ }^{\circledR}$ scintillation cocktail in a Wallac 1409 liquid scintillation counter. The total binding was defined as that measured in the absence of a competing agent. Non-specific binding was determined in the presence of $10 \mu \mathrm{M}$ unlabelled prazosine for $\alpha_{1}$ - and dihydroalprenolol for $\beta$-adrenergic receptors. All assays were carried out at least three times in duplicate, and values are given as means \pm SEM. The binding capacity $\left(B_{\max }\right)$ and $K_{d}$ of values were calculated according to Rosenthal (7). Competition data was analyzed using the program LIGAND (8), utilizing a nonlinear least squares fitting algorithm.

\section{Materials}

The following drugs were used for EFS experiments: fenoterol (Boehringer,Ingelheim, Germany), phentolamine (Ciba-Geigy A.G., Germany), terbutaline (ASTRA, Sweden), urapidil (Byk Gulden, Germany), and yohimbine (Sigma-Aldrich Ltd., Hungary). Drugs were added to the organ bath in a volume of $100 \mu \mathrm{L}$ aqueous solution. [ $\left.{ }^{3} \mathrm{H}\right]$ Prazosine $(72 \mathrm{Ci} / \mathrm{mM})$ and $\left[{ }^{3} \mathrm{H}\right]$ dihydroalprenolol $(94 \mathrm{Ci} / \mathrm{mM}$ ) (Amersham, England) were used in the receptor assays.

\section{Results}

The EFS-stimulated uterine contractions were inhibited concentration-dependently by the selective $\beta_{2}$-agonists terbutaline and fenoterol in the range of $2.5 \times 10^{-7}-3.2 \times 10^{-5} \mathrm{M}$ (Figure 1).

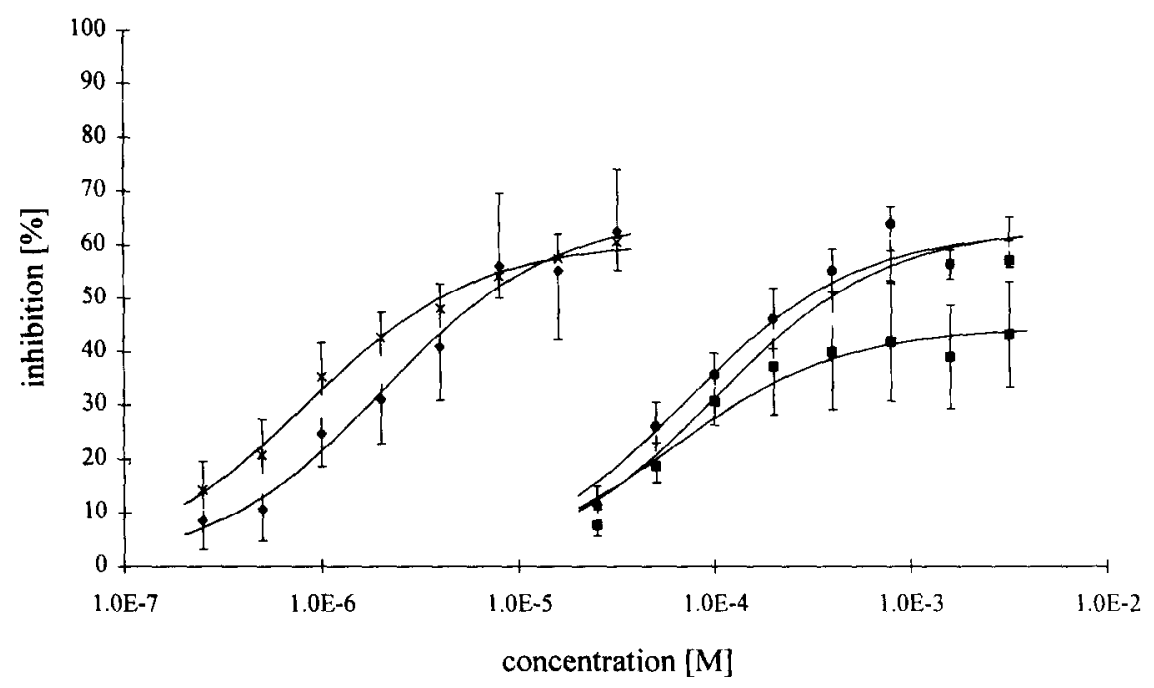

Fig. 1

Effects of $\beta_{2}$-agonists and $\alpha$-antagonists on uterine contractions in vitro.The data are the averages of the results from six experiments \pm S.E.M. Fenoterol $(x)$, terbutaline $(\diamond)$, yohimbin $(\bullet)$, urapidil $(+)$, phentolamine $(\boldsymbol{\square})$. 
The affinity of fenoterol was approximately twice that of terbutaline. However, there were no differences in maximal inhibitory activity between the two drugs (Table I).

\section{TABLE I}

$\mathrm{EC}_{50}$ and maximal inhibition values of $\beta_{2}$-agonists and $\alpha$-antagonists on postpartum rat myometrium

\begin{tabular}{|c|c|c|}
\hline Drug name & EC $_{\mathbf{5 0}}$ value $[\mathbf{M}] \pm$ SEM. & Maximal inhibition [\%] \pm SEM. \\
\hline fenoterol & $8.5 \times 10^{-7} \pm 1.0 \times 10^{-7}$ & $60.8 \pm 1.1$ \\
\hline terbutaline & $2.1 \times 10^{-6} \pm 3.0 \times 10^{-7}$ & $63.5 \pm 1.4$ \\
\hline phentolamine & $6.2 \times 10^{-5} \pm 1.3 \times 10^{-5}$ & $44.7 \pm 2.0$ \\
\hline urapidil & $1.0 \times 10^{-4} \pm 9.7 \times 10^{-6}$ & $63.5 \pm 1.4$ \\
\hline yohimbine & $7.5 \times 10^{-5} \pm 1.9 \times 10^{-5}$ & $63.0 \pm 2.9$ \\
\hline
\end{tabular}

$\mathrm{EC}_{50}$ : concentration causing $50 \%$ of the maximal inhibitory effect

Similarly to the $\beta$-agonists, the non-selective $\alpha$-antagonist phentolamine, the selective $\alpha_{1}$ antagonist urapidil and the selective $\alpha_{2}$-antagonist yohimbine in the concentration range $2.5 \times 10^{-5}$ $3.2 \times 10^{-3} \mathrm{M}$ decreased the uterine contractions (Figure 1). There were no significant differences in affinity between the three drugs, but the maximal inhibition by phentolamine lagged about $20 \%$ behind those of urapidil and yohimbine (Table I). The effects of the $\beta$-agonists and $\alpha$-antagonists were also measured in the presence of $3 \times 10^{-6} \mathrm{M}$ bretylium, but no changes were found.

In the receptor binding assays, we found that the maximal number of binding sites $\left(B_{\max }\right)$ for the $\alpha_{1}$-receptors was $720 \pm 54 \mathrm{fmol} / \mathrm{mg}$ protein, while that for the $\beta$-receptors was $337 \pm 33$ $\mathrm{fmol} / \mathrm{mg}$ protein. The calculated $\alpha_{1} / \beta$ ratio was 2.13 .

\section{Discussion}

Pregnancy-denervated rat uterine muscle was investigated by EFS. The appropriate pulse parameters prove the separated stimulation of the tissue innervation and the smooth muscle. The fast $\mathrm{Na}^{+}$-channels of the transmural nerves can be selectively stimulated by a short pulse duration (0.5-5.0 ms), as can the slow $\mathrm{Ca}^{2+}$-channels of the smooth muscle by a long pulse duration (60$133 \mathrm{~ms}$ ) (9). Therefore, the $100 \mathrm{~ms}$ pulse duration used in our experiments precludes the possibility of any significant nerve excitation. This is supported by the histological facts mentioned earlier. Addition of the adrenergic blocking agent bretylium to the organ bath did not alter the intensity of the contractions which suggests that endogenous noradrenaline has no role in the mechanism of stimulated contractions. The postpartum uterus $24 \mathrm{~h}$ after delivery is histologically equivalent to the last-term pregnant uterus becausc the regeneration of the sympathetic nerves is very slow: it takes about 1 month (10). These facts lead us to suggest that our model is applicable for the investigation of nerve-independent, smooth muscle joint adrenoceptors of the myometrium.

We found that $\beta_{2}$-agonists and $\alpha$-antagonists inhibited the rhythmic uterine contractions elicited by EFS. This effects of the $\beta_{2}$-agonists terbutaline and fenoterol could be connected with their intracellular cAMP-increasing effects (11) The relaxant effect of the selective $\alpha_{2}$-antagonist yohimbine could play a role in the blockade of the $\alpha_{2}$-receptor-linked $\mathrm{Ca}^{2+}$-channels (12), besides the increase in the cAMP level (13). It is very probable that the inhibitory effect of the selective $\alpha_{1}$-antagonist urapidil can be explained by inhibition of those $\mathrm{Ca}^{2+}$-channels 
functionally coupled to the $\alpha_{1}$-receptor subtypes (14). A further explanation may be given the inhibition of endogenous ATP-release by the $\alpha_{1}$-receptor blockers (15). The effect of the nonselective $\alpha$-blocker phentolamine probably involves the mechanisms of urapidil and yohimbine mentioned ahove

The rather high effective concentration of $\beta_{2}$-agonists $\left(2.5 \times 10^{-7}-3.2 \times 10^{-5} \mathrm{M}\right)$ can be explained by the effect of gestational age on tachyphylaxis in the pregnant rat myometrium (16). However, we have not clear explanation of high effective concentration of $\alpha$-blockers $\left(2.5 \times 10^{-5}\right.$. $3.2 \times 10^{-3} \mathrm{M}$ ). The clarification of this question requires further investigations.

The similar in vitro inhibitory activities of the $\beta_{2}$-agonists, urapidil and yohimbine are surprising in view of the fact that $\beta_{2}$-agonists are so effective in the clinical practice of tocolysis that $\alpha$-blocker are not used at all at present. The equivalent inhibitory actions of the two groups could be explained by the receptor binding assay results in which we demonstrated a higher density of $\alpha_{1}$-receptors as compared to that of $\beta_{2}$-receptors. It is known that the $\alpha_{1} / \alpha_{2}$ ratio in the rat uterus is about $1(17)$.

Our results lead us to suggest that the effects of $\beta_{2}$-agonists and $\alpha$-antagonists are mediated through the non-synaptic adrenoceptors in the postpartum rat uterus. A number of papers have been published on the extrasynaptic functions of $\alpha_{2}$ - and $\beta_{2}$-receptors $(18,19,20)$. However, $\alpha_{1}$-receptors are currently considered to be situated only intrasynaptically (21). Our results suggest that the non-synaptic $\alpha_{1}$-adrenoceptors play an important role in the regulation of the pregnant rat uterus and in delivery. This is supported by the fact that $\alpha_{1}$-blockers (prazosine and urapidil) inhibited spontaneous postpartum rat uterus contractions in vivo (22). To best of our knowledge, our results afford the first functional proof of the existence of non-synaptic $\alpha_{1}$ adrenoceptors in smooth muscle such as the postpartum rat myometrium.

\section{Acknowledgement}

The authors thank the Nagai Foundation (Tokyo, Japan) for supporting the project. Special thank Judit Czinkota for assistance in the experiments.

\section{References}

1. E. BORDA, J. SAUVAGE, L. STERIN-BORDA, M.F. GIMENO and A.L. GIMENO, Eur.J.Pharniacul. 56 61-67 (1979)

2. M. ELMER, P. ALM and G. THORBERT, Acta.Physiol.Scand. 108 209-213. (1980)

3. R. BULAT, M.S. KANNAN and R.E. GARFIELD, Can.J.Physiol.Pharmacol. 67 837-844 (1988)

4. N. MORIZAKI, J. MORIZAKI, R.H. HAYASHI and R.E.GARFIELD, Am.J.Obstet.Gynecol. 160 218-228 (1989)

5. F.A. MOUSTAFA, Acta.Anat.Basel. 132 310-316 (1988)

6. G. THORBERT, P. ALM, A.B. BJORKLUND, C. OWMAN and N.O. SJOBERG, Am.J.Obstet.Gynecol. 135 223-226 (1979)

7. H.E.ROSENTHAL, Anal.Biochem. 20525 (1967)

8. P.J.MUNSON and D.ROADBARD, Anal.Biochem. 107220 (1980)

9. T. TOMITA, Electrical properties of mammalian smooth muscle, in: Smooth muscle, $\mathrm{E}$. Bulbring, A.F. Brading, A.W. Jones, T. Tomita (Eds), 197-243, Edward Arnold, London (1970) 
10. M. YAMADA, Nippon.Sanka.Fujinka.Gakkai.Zasshi. 40 145-152 (1988)

11. R.G. ANDERSSON, G.BERG, S.R.JOHANSSON and G.RYDEN, Gynecol.Obstet.Invest. 11 268-293 (1980)

12. J.Y. LEE and J.F. DEBERNARDIS, Methods.Find.Clin.Phamacol. 12 213-215 (1990)

13. M. BREUILLER, B. ROVOT, M.H. LITIME, M.J. LEROY and F. FERRE, J.Clin.Endocrinol.Metab. 70 1299-1304 (1990)

14. M.T. PIASCIK, B.T. BUTLER, T.A. PRUITT and J.W. KUSIAK, J.Pharmacol.Exp.Ther. 254 982-991 (1990)

15. E.S. VIZI, B.S. SPERLAGH and M. BARANYI, Neuroscience. 50 455-465 (1992)

16. C. YEAGLEY, S.N. CARITIS and A.L. RUZYCKY, Am.J.Obstet.Gynecol. 174 1637$1642(1996)$

17. J.P. MALTIER and C. LEGRAND, Eur.J.Pharmacol. 117 1-13 (1985)

18. P. VAN BRUMMELEN, K. JIE, P.B. TIMMERMANS and P.A. VAN ZWIETEN, Can.J.Physiol.Pharmacol. 65 1644-1648 (1987)

19. G. PARRITT, G. AMBROSINI, M. SALLESE AND A. DE-BLASI, J.Recept.Res. 13 609-618 (1993)

20. J.P. SPRINGER, B.P. KROPP and K.B. THOR, J.Urol. 152 515-519 (1994)

21. K. JIE, P. VAN BRUMMELEN, P. VERMEY, P.B. TIMMERMANS and P.A.VAN ZWIETEN, J.Hypertens. 3 Suppl. 3 S145-S147 (1985)

22. I. ZUPKÓ, R. GÁSPÁR, L. KOVÁCS and G. FALKAY, Life Sci. 61 PL159-PL163 (1997) 